OPEN ACCESS

Edited by:

Hubert Vaudry,

University of Rouen, France

Reviewed by:

Gábor B. Makara,

Hungarian Academy of

Sciences, Hungary

Stanko S. Stojilkovic,

National Institutes of Health, USA

*Correspondence:

Masaru Shoji

msji@my-pharm.ac.jp

Specialty section:

This article was submitted to Neuroendocrine Science,

a section of the journal

Frontiers in Endocrinology

Received: 20 January 2017

Accepted: 11 April 2017

Published: 28 April 2017

Citation:

Ohta T, Mita M, Hishinuma S, Ishii-Nozawa R, Takahashi $K$ and Shoji M (2017) Inhibition of Ectopic Arginine Vasopressin Production by

Phenytoin in the Small Cell Lung

Cancer Cell Line Lu-165.

Front. Endocrinol. 8:94.

doi: 10.3389/fendo.2017.00094

\section{Inhibition of Ectopic Arginine Vasopressin Production by Phenytoin in the Small Cell Lung Cancer Cell Line Lu-165}

\author{
Takahiro Ohta 1,2, Mitsuo Mita1 , Shigeru Hishinuma ${ }^{1}$, Reiko Ishii-Nozawa ${ }^{3}$, \\ Kazuhisa Takahashi ${ }^{4}$ and Masaru Shoji ${ }^{1 *}$

\begin{abstract}
'Department of Pharmacodynamics, Meiji Pharmaceutical University, Kiyose, Japan, ${ }^{2}$ Department of Pharmacy, National Cancer Center Hospital East, Kashiwa, Japan, ${ }^{3}$ Department of Clinical Pharmaceutics, Meiji Pharmaceutical University, Kiyose, Japan, ${ }^{4}$ Faculty of Medicine, Department of Respiratory Medicine, Juntendo University, Tokyo, Japan
\end{abstract}

Phenytoin, a voltage-gated sodium channel (Nav channel) antagonist, reportedly inhibits arginine vasopressin (AVP) release from an isolated rat neurohypophysis. So far, it is uncertain whether phenytoin has a direct action on ectopic AVP-producing neuroendocrine tumors. We studied the effect of phenytoin on the release of copeptin, the C-terminal fragment of pro-AVP, and expression of AVP gene in the human small cell lung cancer cell line Lu-165. Cells were maintained in RPMl1640 medium with 10\% fetal bovine serum and were used within the fifth passage. Copeptin was detected using a new sandwich immunoassay, and AVP mRNA levels were measured using real-time reverse transcription polymerase chain reaction. Treatment with phenytoin at a concentration of $25 \mu \mathrm{g} / \mathrm{mL}$, but not at 5 or $10 \mu \mathrm{g} / \mathrm{mL}$, had an inhibitory effect on copeptin levels in the medium at $48 \mathrm{~h}$. At the same concentration, AVP mRNA levels in Lu-165 cells also decreased. Although a sodium challenge with added sodium at $20 \mathrm{mEq} / \mathrm{L}$ increased copeptin levels in the medium, a sodium challenge with added sodium at 10 and $20 \mathrm{mEq} / \mathrm{L}$ had no effect on AVP mRNA levels. Phenytoin at a concentration of $25 \mu \mathrm{g} / \mathrm{mL}$ suppressed copeptin levels in the medium under the sodium challenge with added sodium at 10 and $20 \mathrm{mEq} / \mathrm{L}$. Phenytoin at a concentration of $25 \mu \mathrm{g} / \mathrm{mL}$ also decreased AVP mRNA levels in Lu-165 cells under the sodium challenge with added sodium at $10 \mathrm{mEq} / \mathrm{L}$, but not at $20 \mathrm{mEq} / \mathrm{L}$. Among five tested Nav channel subunits, Nav1.3 was highly expressed in Lu-165 cells. However, phenytoin significantly decreased Nav1.3 mRNA levels under the sodium challenge with added sodium at 10 and $20 \mathrm{mEq} / \mathrm{L}$. These results suggest that Lu-165 cells are sensitive to phenytoin and sodium to control of AVP release and its gene expression. Phenytoin might have a direct action on ectopic AVP-producing tumors, suggesting the importance of $\mathrm{Nav}$ channels in AVP-producing neuroendocrine tumors.

Keywords: phenytoin, vasopressin, copeptin, voltage-gated sodium channel, small cell lung cancer, syndrome of inappropriate antidiuretic hormone secretion 


\section{INTRODUCTION}

Phenytoin, a voltage-gated sodium channel ( $\mathrm{Na}_{\mathrm{V}}$ channel) antagonist, is widely used as an anticonvulsant drug in epileptic patients (1). In addition, phenytoin is effective in the treatment of syndrome of inappropriate antidiuretic hormone [arginine vasopressin (AVP)] secretion (SIADH) with abnormalities of the hypothalamic-pituitary axis (2). Phenytoin was found to inhibit AVP release from an isolated rat neurohypophysis (3). It is well known that small cell lung cancer (SCLC), one of the most aggressive forms of cancer, is sometimes complicated with refractory hyponatremia because SCLC is one of neuroendocrine tumors with capability of producing AVP (4-6). However, so far, it is uncertain whether phenytoin has a direct action on ectopic AVP-producing SCLC cells.

$\mathrm{Na}_{v}$ channel is a heterodimer composed of a single poreforming $\alpha$ subunit and two associated $\beta$ subunits (7). To date, nine $\alpha$ subunits and four $\beta$ subunits have been identified. $\mathrm{Na}_{\mathrm{v}}$ channels play a critical role in the depolarization of excitable cells, including skeletal muscle cells, cardiomyocytes, and neurons. Indeed, four $\mathrm{Na}_{v}$ channel subunits were found in magnocellular neurons in the hypothalamic supraoptic nucleus, and the expression and electrical activity of these subunits appeared to be salt sensitive (8). Recently, the role of $\mathrm{Na}_{\mathrm{v}}$ channels in non-excitable cells has drawn attention (9). Cancer cells express certain $\mathrm{Na}_{\mathrm{V}}$ channel subtypes. Cancer cell lines with higher $\mathrm{Na}_{\mathrm{v}}$ channel expression show increased cell motility and metastatic potential; however, conflicting results have been reported (7). Notwithstanding, there is little evidence on the expression and role of $\mathrm{Na}_{\mathrm{v}}$ channels in AVP-producing SCLC cells.

In the present study, we examined the effect of phenytoin with and without a sodium challenge on AVP mRNA expression and the release of copeptin, the C-terminal fragment of pro-AVP (10), in the human SCLC cell line Lu-165. Lu-165 cells were previously established from a 50-year-old SCLC patient with SIADH (11).

\section{MATERIALS AND METHODS}

\section{Cell Culture}

The AVP-producing SCLC cell line Lu-165 and three AVP non-producing SCLC cell lines, Lu-24, Lu-134A, and MS-1, were provided by RIKEN BRC through the National BioResource Project of the MEXT, Japan. These cells were maintained in RPMI1640 medium with 10\% fetal bovine serum (FBS) in a humidified incubator at $37^{\circ} \mathrm{C}$ with $5 \% \mathrm{CO}_{2}$. All cells were used during exponential growth within the fifth passage for experiments without FBS.

\section{Phenytoin Treatment and the Sodium Challenge}

Small cell lung cancer Lu-165 cells were counted and inoculated at a density of approximately $5 \times 10^{5}$ cells/well in 24 -well cell culture plates containing RPMI1640 medium $(980 \mu \mathrm{L})$. After a 48 -h exposure to either the drug vehicle (dimethyl sulfoxide) or three concentrations of phenytoin (Sigma Chemical Co., St. Louis,
MO, USA) $(5,10$, or $25 \mu \mathrm{g} / \mathrm{mL})$ that span the therapeutic range $(10-20 \mu \mathrm{g} / \mathrm{mL})$, cells and culture media were separately collected and stored at $-20^{\circ} \mathrm{C}$ for later measurement. For the sodium challenge, RPMI1640 media with high sodium concentrations were prepared by adding sodium chloride (Sigma-Aldrich, St. Louis, MO, USA) at $10 \mathrm{mEq} / \mathrm{L}$ (added $10 \mathrm{mEq} / \mathrm{L}$ ) or at $20 \mathrm{mEq} / \mathrm{L}$ (added $20 \mathrm{mEq} / \mathrm{L}$ ) to the basal RPMI1640 medium. The sodium concentration of the basal RPMI1640 medium was $139.5 \pm 0.1 \mathrm{mEq} / \mathrm{L}$ (mean \pm SE, $n=6$ ). For the sodium challenge, cells were treated with the vehicle or phenytoin $(25 \mu \mathrm{g} / \mathrm{mL})$ in RPMI1640 media with added sodium at 10 or $20 \mathrm{mEq} / \mathrm{L}$ for $48 \mathrm{~h}$.

\section{Copeptin Measurement}

The copeptin level (picomoles per liter) in the medium was detected with a new sandwich immunoassay (Peninsula Laboratories International, San Carlos, CA, USA) after C18 Sep-Column extraction following the manufacturer's recommendations, as previously reported (12).

\section{Real-time Polymerase Chain Reaction}

The mRNA levels of AVP and $\mathrm{Na}_{\mathrm{V}}$ channel subunits were measured using real-time reverse transcription polymerase chain reaction (RT-PCR). Complementary DNA was obtained from cultured cells using a FastLane Cell cDNA Kit (QIAGEN, Tokyo, Japan) following the manufacturer's protocol. Custom Applied Biosystem TaqMan ${ }^{\circledR}$ Expression Assays (Thermo Fisher Scientific Inc., Yokohama, Japan) were used with Applied Biosystems ${ }^{\circledR}$ 7500 Fast real-time PCR system (Thermo Fisher Scientific Inc., Yokohama, Japan) following the manufacturer's protocol. All RT-PCR reagents contained a TaqMan FAM-MGB probe and two unlabeled, specific custom primers for each target sequence. For the relative quantification of RNA expression, the mRNAs of human AVP and the following human $\mathrm{Na}_{\mathrm{v}}$ channel subunits were tested: $\beta 1, \mathrm{Na}_{v} 1.3, \mathrm{Na}_{v} 1.5, \mathrm{Na}_{v} 1.6$, and $\mathrm{Na}_{v} 1.7$. Human 18S-ribosomal RNA (18S rRNA) was used as an internal control. The difference between the cycle threshold values of each gene and the $18 \mathrm{~S}$ rRNA gene was calculated for each experimental sample using the software of 7500 Fast System.

\section{Statistical Analysis}

Continuous variables were expressed as means \pm SEs. For group comparisons, the Tukey multiple comparison test or the paired $t$-test was used following one-way or two-way analysis of variance where appropriate. The data of RT-PCR were normalized by logarithmic transformation. Statistical analyses were performed using GraphPad Prism 6.0 (GraphPad Software Inc., CA, USA). A two-tailed probability value of $<0.05$ was considered statistically significant.

\section{RESULTS}

\section{Comparison of AVP mRNA Levels among the Four SCLC Cell Lines}

Reverse transcription polymerase chain reaction showed high levels of AVP mRNA in Lu-165 cells, but not in Lu-24, Lu-134A, or MS-1 cells (Figure 1). 


\section{Effects of Phenytoin on Copeptin Levels in the Medium and AVP mRNA Levels in Lu-165 Cells}

Copeptin levels in the medium significantly decreased after the 48 -h treatment of phenytoin at doses of $25 \mu \mathrm{g} / \mathrm{mL}$, but not of 5 or $10 \mu \mathrm{g} / \mathrm{mL}$ (Figure 2A). Copeptin levels in the group without phenytoin were $6.7 \pm 0.5 \mathrm{pmol} / \mathrm{L}$, which were significantly different $(p<0.01)$ from $3.9 \pm 0.3 \mathrm{pmol} / \mathrm{L}$ in the group with phenytoin at doses of $25 \mu \mathrm{g} / \mathrm{mL}$ (Figure 2A). Relative AVP mRNA levels in Lu-165 cells also decreased after the 48-h treatment of phenytoin at doses of $25 \mu \mathrm{g} / \mathrm{mL}$ (Figure 2B). There was a significant difference $(p<0.01)$ in relative AVP mRNA levels between the group without phenytoin $(1.00 \pm 0.36)$ and the group with phenytoin at doses of $25 \mu \mathrm{g} / \mathrm{mL}(0.13 \pm 0.04)$ (Figure 2B).

\section{Effects of Phenytoin on Copeptin Levels in the Medium and AVP mRNA Levels in Lu-165 Cells under the Sodium Challenge}

The sodium challenge with added sodium at 10 and $20 \mathrm{mEq} / \mathrm{L}$ increased copeptin levels in the medium in an upward trend.

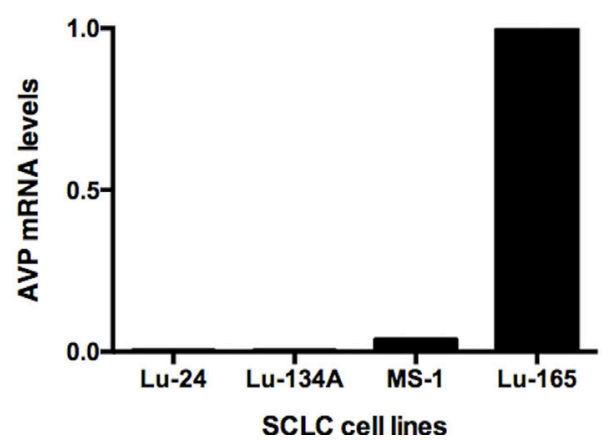

FIGURE 1 | Comparison of arginine vasopressin (AVP) mRNA levels among the four small cell lung cancer (SCLC) cell lines Lu-24, Lu-134A, MS-1, and Lu-165 $(n=1)$
The copeptin levels of $17.7 \pm 1.2 \mathrm{pmol} / \mathrm{L}$ at added $20 \mathrm{mEq} / \mathrm{L}$ was significantly higher $(p<0.05)$ than those of $9.2 \pm 2.3 \mathrm{pmol} / \mathrm{L}$ without sodium challenge (added $0 \mathrm{mEq} / \mathrm{L}$ ). The 48 -h treatment of phenytoin at a dose of $25 \mu \mathrm{g} / \mathrm{mL}$ significantly decreased copeptin levels in the medium under the sodium challenge with added sodium at $10 \mathrm{mEq} / \mathrm{L}(p<0.01)$ and at $20 \mathrm{mEq} / \mathrm{L}(p<0.05)$ (Figure 3A). Although AVP expression levels did not change under the sodium challenges, they significantly decreased in the presence of $25 \mu \mathrm{g} / \mathrm{mL}$ phenytoin under the sodium challenge at added $10 \mathrm{mEq} / \mathrm{L}(p<0.05)$ (Figure 3B).

\section{$\mathrm{Na}_{v}$ Channel Subunit mRNA Levels in Lu-165 Cells}

We measured the mRNA levels of $\mathrm{Na}_{\mathrm{v}}$ channel subunits, including $\beta 1, \mathrm{Na}_{v} 1.3, \mathrm{Na}_{v} 1.5, \mathrm{Na}_{v} 1.6$, and $\mathrm{Na}_{v} 1.7$ in Lu-165 cells. Among the five subunits, $\mathrm{Na}_{v} 1.3$ was dominantly expressed. The $\mathrm{Na}_{v} 1.3$ mRNA levels in Lu-165 cells were significantly higher than the mRNA levels in any other $\mathrm{Na}_{\mathrm{v}}$ channel subunits $(p<0.05-0.01)$ (Figure 4).

\section{Effects of Phenytoin on mRNA Levels of Nav1.3 in Lu-165 Cells under the Sodium Challenge}

The sodium challenge with added sodium at 10 and $20 \mathrm{mEq} / \mathrm{L}$ did not affect $\mathrm{Na}_{\mathrm{v}} 1.3 \mathrm{mRNA}$ levels. The 48 -h treatment of phenytoin at a dose of $25 \mu \mathrm{g} / \mathrm{mL}$ significantly $(p<0.05)$ reduced $\mathrm{Na}_{v} 1.3$ mRNA levels under the sodium challenge with added sodium at 10 and $20 \mathrm{mEq} / \mathrm{L}$ (Figure 5).

\section{DISCUSSION}

It was previously uncertain whether phenytoin has a direct action on ectopic AVP-producing neuroendocrine tumors. The present study clearly demonstrates that Lu-165 cells expressed AVP mRNA and released copeptin and that a slightly greater than therapeutic dose of phenytoin reduced intracellular AVP mRNA levels and AVP surrogate copeptin concentrations in the medium
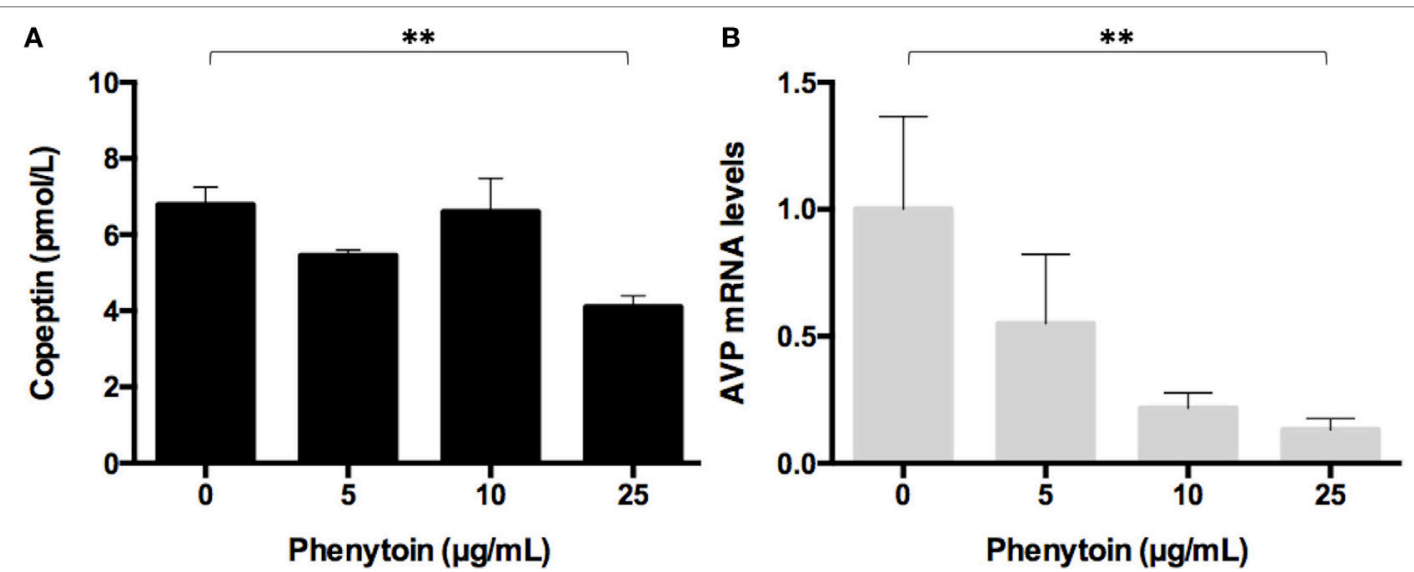

FIGURE 2 | Effect of three doses of phenytoin treatment (48 h) on copeptin levels in the medium $(n=4)(A)$ and arginine vasopressin (AVP) mRNA levels in Lu-165 cells $(n=5)(B)(* * p<0.01)$ 

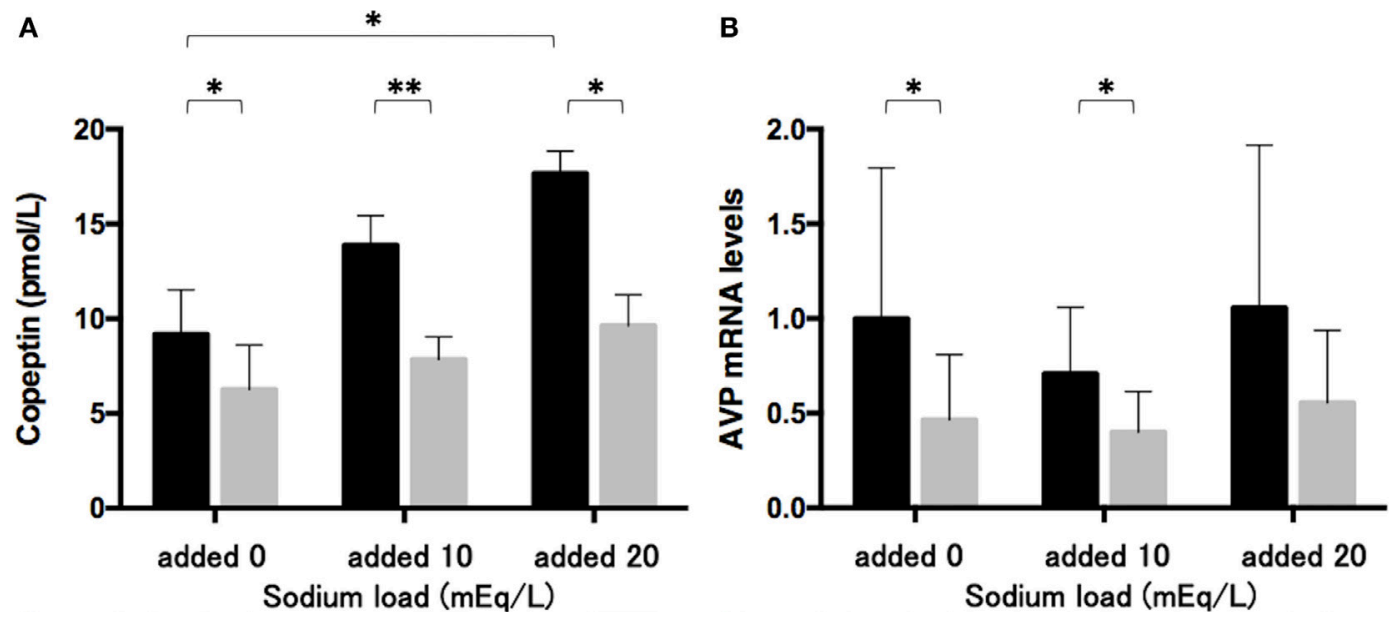

FIGURE 3 | Effects of phenytoin on copeptin levels in the medium $(n=4)(A)$ and arginine vasopressin (AVP) mRNA levels in Lu-165 cells under the sodium challenge $(\boldsymbol{n}=6)(B)$. Black columns for phenytoin $(-)$ and gray columns for phenytoin $(+)\left({ }^{\star} p<0.05,{ }^{* *} p<0.01\right)$.

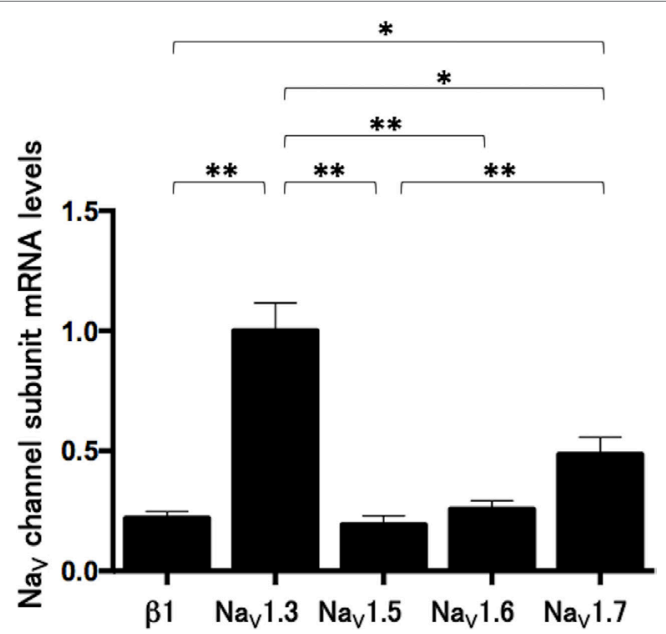

FIGURE 4 | Voltage-gated sodium channel ( $\mathrm{Na}_{\mathrm{v}}$ channel) subunit mRNA levels in small cell lung cancer Lu-165 cells $(n=6)\left({ }^{*} p<0.05\right.$, $\left.{ }^{\star *} p<0.01\right)$

of SCLC Lu-165 cells. SCLC Lu-165 cells were sensitive to the sodium load for increasing copeptin secretion and insensitive to increase AVP mRNA expression. Phenytoin downregulated those responses in Lu-165 cells.

Physiologically, AVP biosynthesis in the hypothalamic-pituitary axis and its secretion from the posterior pituitary is mainly regulated by peripheral signals from the osmoreceptors and baroreceptors (13). Conversely, ectopic AVP biosynthesis in AVP-producing neuroendocrine tumors appeared autonomous. However, there are some factors for controlling ectopic AVP biosynthesis (5). Verbeeck et al. (14) showed that cAMP and protein kinase-C pathways as well as glucocorticoid receptors are involved in the regulation of AVP mRNA levels in human SCLC GLC-8 cells. The present study indicates the involvement of phenytoin action in AVP gene expression and release in SCLC cells.

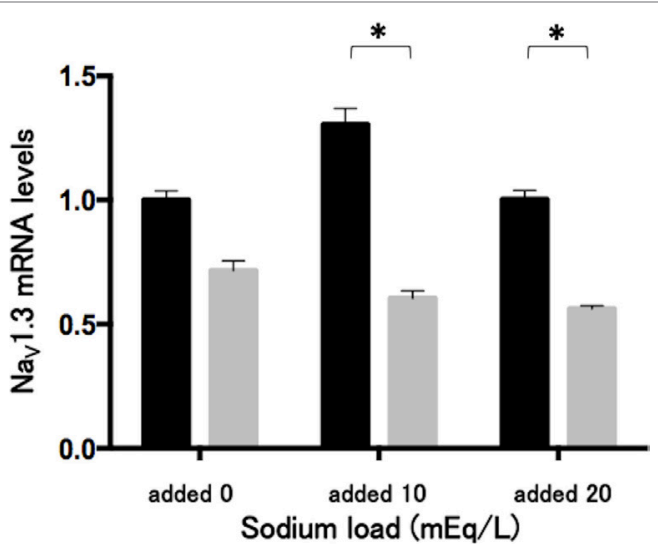

FIGURE 5 | Effects of phenytoin dose of $25 \mu \mathrm{g} / \mathrm{mL}$ on mRNA levels of voltage-gated sodium channel subunit Nav1.3 in Lu-165 cells under the sodium challenge $(\boldsymbol{n}=6)$. Black columns for phenytoin $(-)$ and gray columns for phenytoin $(+)\left({ }^{*} p<0.05\right)$.

Guzek et al. (3) reported that $40 \mu \mathrm{g} / \mathrm{mL}$ of phenytoin inhibited AVP release from an isolated rat neurohypophysis. Niewiadomski (15) found that the intraperitoneal administration of phenytoin at a dose of $100 \mathrm{mg} / 100 \mathrm{~g}$ body weight diminished the vasopressin level in the hypothalamus and neurohypophysis of euhydrated and dehydrated rats. These findings are consistent with the results of the present study. Therefore, there seems to be common mechanisms mediating the phenytoin-induced inhibition of AVP biosynthesis and release in the hypothalamo-neurohypophysis and malignant cells.

Since 1968, phenytoin has been widely used with much clinical success against all types of epileptiform seizures except absence seizures (1). At therapeutic concentrations in blood, the effect of phenytoin is mediated by slowing the rate of recovery of $\mathrm{Na}_{\mathrm{v}}$ channel from activation $(1,16)$. However, at toxic concentrations, 10 times higher than therapeutic concentrations, multiple 
effects of phenytoin are evident, including the enhancement of responses to GABA (16). As the phenytoin dose of $25 \mu \mathrm{g} / \mathrm{mL}$ used in the present study is slightly higher than the therapeutic range, there may be mechanisms other than $\mathrm{Na}_{\mathrm{V}}$ channel that mediate the effect of phenytoin on AVP gene expression and secretion in Lu-165 cells, which may be elucidated by electrophysiological analysis and sodium transport evaluation in future studies.

In the present study, we confirmed the gene expression of $\mathrm{Na}_{\mathrm{V}}$ channel subunits, including $\beta 1, \mathrm{Na}_{v} 1.3, \mathrm{Na}_{v} 1.5, \mathrm{Na}_{v} 1.6$, and $\mathrm{Na}_{v} 1.7$, in SCLC Lu-165 cells; however, other subunits were not examined. Among these subunits, $\mathrm{Na}_{\mathrm{v}} 1.3$ was dominantly expressed in SCLC Lu-165 cells. Under the sodium challenged condition, $\mathrm{Na}_{\vee} 1.3$ was found to be downregulated by a phenytoin dose of $25 \mu \mathrm{g} / \mathrm{mL}$. Nav 1.3 is one of the six tetrodotoxin-sensitive $\mathrm{Na}_{\mathrm{V}}$ channel $\alpha$ subunits (7). Kwong and Carr (9) reported that antiepileptic drugs, including phenytoin, target the local anesthetic site located in domain IVS6. This site is highly conserved among $\alpha$ subunits. Lucas et al. (17) reported that phenytoin suppressed the membrane potential in $\mathrm{Na}_{v} 1.3$ that is overexpressed in Chinese hamster ovary cells. These findings suggest that $\mathrm{Na}_{v} 1.3$ is one of the candidate molecules for mediating phenytoin action in Lu-165 cells.

Conflicting relationships between $\mathrm{Na}_{\mathrm{V}}$ channel expression and metastatic potential have been identified in several cell lines and clinical situations using biopsy samples $(7,18)$. In addition, there has been a discrepancy in the efficacy of phenytoin for controlling epileptic seizures (1). Even with optimal treatment, $20-30 \%$ of all epilepsy patients are pharmacoresistant (19). Mutations in genes encoding $\mathrm{Na}_{\mathrm{v}}$ channel subunits are anticipated to explain drug resistance. Variability in $\mathrm{Na}_{\mathrm{V}}$ channel genotypes is likely to account for the heterogeneity of the clinical effects of phenytoin (19). In addition, the effects of phenytoin in treating SIADH are controversial (20-22). The relationship between the pharmacotherapeutic effects of phenytoin and gene variations is uncertain. Therefore, SCLC cells and tissues other than Lu-165 cells may not respond to phenytoin. The present findings suggest that at least some forms of SCLC respond to phenytoin treatment. We speculated that the genotype analysis of the phenytoin responsive domain in Lu-165 cells is the key to predicting favorable clinical responses to phenytoin in patients with SIADH. Additionally, the mutational analysis and RNA interference study of $\mathrm{Na}_{\mathrm{v}}$ channels could confirm the direct involvement of $\mathrm{Na}_{\mathrm{V}}$ channels in controlling ectopic AVP expression in neuroendocrine tumors.

\section{REFERENCES}

1. Vajda FJ, Eadie MJ. The clinical pharmacology of traditional antiepileptic drugs. Epileptic Disord (2014) 16:395. doi:10.1684/epd.2014.0704

2. Miyagawa CI. The pharmacologic management of the syndrome of inappropriate secretion of antidiuretic hormone. Drug Intell Clin Pharm (1986) 20:527-31.

3. Guzek JW, Russel JT, Thorn NA. Inhibition of diphenylhydantoin of vasopressin release from isolated rat neurohypophyses. Acta Pharmacol Toxicol (Copenh) (1974) 34:1-4. doi:10.1111/j.1600-0773.1974.tb01550.x

4. Shoji M, Kimura T, Ota K, Yamaji T, Ishibashi M, Ohta M, et al. Genotype analysis of prepro-vasopressin signal peptide in vasopressin-producing and -non-producing lung tumors. Life Sci (1997) 61:2561-6. doi:10.1016/ S0024-3205(97)01010-2

\section{CONCLUSION}

The results of the present study suggest that the SCLC cell line Lu-165 is sensitive to the phenytoin regulation of AVP release and gene expression. In Lu-165 cells, the $\mathrm{Na}_{\mathrm{V}}$ channel subunit $\mathrm{Na}_{\mathrm{V}} 1.3$ was dominantly expressed and it might be one of the candidate molecules for mediating phenytoin action. Further studies are required to elucidate the underlying mechanisms of phenytoin action.

\section{ETHICS STATEMENT}

Because the present study used established non-infectious cell lines without gene manipulation, ethics approval was not needed as per the institutional guidelines. In addition, the supplier Riken $\mathrm{BRC}$ stated that there is no restriction regarding academic use of four cell lines.

\section{AUTHOR CONTRIBUTIONS}

TO and MS contributed to the study design, data collection and analysis, interpretation of results, and writing and revising the manuscript. MM and SH contributed to the study design, data collection and interpretation of results and assisted in revising the manuscript. RI-N contributed to data collection and interpretation of results and assisted in revising the manuscript. KT contributed to the study design and interpretation of results and assisted in writing and revising the manuscript.

\section{ACKNOWLEDGMENTS}

The authors would like to thank Takayuki Nakai, Takahide Tsuda, Hiroki Takahashi, Hiroshi Kushibe, Wakana Niitsu, Mariko Iwai, Asuka Shimura, Mai Mutou, Kenji Yuasa, and Hiroki Ohori for their technical contribution.

\section{FUNDING}

The study was supported in part by MEXT's Promotion Plan for the Platform of Human Resource Development for Cancer project. Four cells were supplied by Riken BRC.

5. Keegan BP, Memoli VA, North WG. Targeting the neurophysin-related cell surface antigen on small cell lung cancer cells using a monoclonal antibody against the glycopeptide region (cMAG-1) of provasopressin. Mol Cancer Ther (2002) 1:1153-9.

6. Castillo JJ, Vincent M, Justice E. Diagnosis and management of hyponatremia in cancer patients. Oncologist (2012) 17:756. doi:10.1634/theoncologist. 2011-0400

7. Kruger LC, Isom LL. Voltage-gated $\mathrm{Na}^{+}$channels: not just for conduction. Cold Spring Harb Perspect Biol (2016) 8:6. doi:10.1101/cshperspect. a029264

8. Tanaka M, Cummins TR, Ishikawa K, Black JA, Ibata Y, Waxman SG. Molecular and functional remodeling of electrogenic membrane of hypothalamic neurons in response to changes in their input. Proc Natl Acad Sci US A (1999) 96:1088-93. doi:10.1073/pnas.96.3.1088 
9. Kwong K, Carr MJ. Voltage-gated sodium channels. Curr Opin Pharmacol (2015) 22:131. doi:10.1016/j.coph.2015.04.007

10. Morgenthaler NG, Struck J, Alonso C, Bergmann A. Assay for the measurement of copeptin, a stable peptide derived from the precursor of vasopressin. Clin Chem (2006) 52:112-9. doi:10.1373/clinchem.2005.060038

11. Terasaki T, Matsuno Y, Shimosato Y, Yamaguchi K, Ichinose H, Nagatsu T, et al. Establishment of a human small cell lung cancer cell line producing a large amount of anti-diuretic hormone. Jpn J Cancer Res (1994) 85:718-22. doi:10.1111/j.1349-7006.1994.tb02420.x

12. Iwashita N, Nara N, Sato R, Nakatogawa T, Kobayashi S, Zama S, et al. Differential regulation of plasma copeptin levels in patients with heart failure: a single-center prospective study. Tohoku J Exp Med (2016) 239:213. doi:10.1620/tjem.239.213

13. Share L. Role of vasopressin in cardiovascular regulation. Physiol Rev (1988) 68:1248-84.

14. Verbeeck MA, Sutanto W, Burbach JP. Regulation of vasopressin messenger RNA levels in the small cell lung carcinoma cell line GLC-8: interactions between glucocorticoids and second messengers. Mol Endocrinol (1991) 5:795-801. doi:10.1210/mend-5-6-795

15. Niewiadomski JS. The hypothalamic and neurohypophysial vasopressin content as influenced by diphenylhydantoin in dehydrated rats. Acta Physiol Pol (1979) 30:351-8.

16. Tunnicliff G. Basis of the antiseizure action of phenytoin. Gen Pharmacol (1996) 27:1091-7. doi:10.1016/S0306-3623(96)00062-6

17. Lucas PT, Meadows LS, Nicholls J, Ragsdale DS. An epilepsy mutation in the betal subunit of the voltage-gated sodium channel results in reduced channel sensitivity to phenytoin. Epilepsy Res (2005) 64:77-84. doi:10.1016/j. eplepsyres.2005.03.003

18. Fraser SP, Ozerlat-Gunduz I, Brackenbury WJ, Fitzgerald EM, Campbell TM, Coombes RC, et al. Regulation of voltage-gated sodium channel expression in cancer: hormones, growth factors and auto-regulation. Philos Trans $R$ Soc Lond B Biol Sci (2014) 3:1638. doi:10.1098/rstb.2013.0105

19. Sharma AK, Rani E, Waheed A, Rajput SK. Pharmacoresistant epilepsy: a current update on non-conventional pharmacological and non-pharmacological interventions. J Epilepsy Res (2015) 5:1. doi:10.14581/jer.15001

20. Okamoto M, Nako Y, Tachibana A, Fujiu T, Ohki Y, Tomomasa T, et al. Efficacy of phenytoin against hyponatremic seizures due to SIADH after administration of anticancer drugs in a neonate. J Perinatol (2002) 22:247-8. doi:10.1038/ sj.jp. 7210657

21. Fichman MP, Kleeman CR, Bethune JE. Inhibition of antidiuretic hormone secretion by diphenylhydantoin. Arch Neurol (1970) 22:45-53. doi:10.1001/ archneur.1970.00480190049008

22. Decaux G, Przedborski S, Soupart A. Lack of efficacy of phenytoin in the syndrome of inappropriate anti-diuretic hormone secretion of neurological origin. Postgrad Med J (1989) 65:456-8. doi:10.1136/pgmj. 65.765 .456

Conflict of Interest Statement: The authors declare that the research was conducted in the absence of any commercial or financial relationships that could be construed as a potential conflict of interest.

Copyright (c) 2017 Ohta, Mita, Hishinuma, Ishii-Nozawa, Takahashi and Shoji. This is an open-access article distributed under the terms of the Creative Commons Attribution License (CC BY). The use, distribution or reproduction in other forums is permitted, provided the original author(s) or licensor are credited and that the original publication in this journal is cited, in accordance with accepted academic practice. No use, distribution or reproduction is permitted which does not comply with these terms. 